Петер ФЕКЕТЕ

\title{
БЕЗПЕКА ВИСТУПУ АРТИСТА СЦЕНІЧНОГО МИСТЕЦТВА: ОСОБЛИВОСТІ ЇЇ ЗАБЕЗПЕЧЕННЯ
}

У статті розглянуто особливості забезпечення безпеки виступу артиста на сиенічних майданчиках. Наголошується специфіка виконавського мистеитва, яка вимагає особливого застосування правил безпеки життя, включає людський фактор і часто покладає відповідальність на технічних фахівців.

Ключові слова: сиенічне мистецтво, техніка безпеки, сиена.

В статье рассматриваются особенности обеспечения безопасности выступления артиста на сиеничных площадках. Подчеркивается специфика исполнительского мастерства, которая требует особого применения правил безопасности жизни, включает человеческий фактор и часто возлагает ответственность на технических специилистов.

Ключевые слова: сиеническое искусство, техника безопасности, сцена.

The article deals with the specifics of ensuring the safety of the artist's performance on the stage stages. The specificity of performing skills is emphasized, which requires special application of the rules of safety of life, includes the human factor and often places responsibility on the hands of technical specialists.

Key words: stage art, safety technique, stage.

Завдання режисера щодо художнього дизайну вистави полягає в тому, щоб знайти таке зовнішне середовище для гри акторів, яке б допомагало їм відкривати зміст кожної сцени та створювати достовірний образ персонажа у виставі. Вочевидь, зовнішні форми сценічної виразності можуть бути різноманітними, й міра сценічної умовності при цьому може бути найрізноманітнішою. Це залежить від особливостей драматургічного твору та його режисерської інтерпретації. Але є обов'язкове правило, якому повинно підкорятися художнє оформлення вистави: воно має бути безпечним для життя актора.

Є правила, які відносно добре страхують життя і гарантують безпеку повсякденної діяльності людини. Адже багато професій є небезпечними для життя, коли працівники по-справжньому ризикують своїм життям. Життєво важливо таку діяльність виконувати точно і безпечно, відповідно до правил, передбачених нормативами безпеки та законом. Оператор крана, будівельник, тесля, промисловий альпініст, водолаз працюють на великих висотах або на запаморочливих глибинах і змушені виконувати заплановане завдання і створювати бажаний «продукт» таким чином, щоб ні виконавець, ні колеги, ні люди в оточенні не постраждали, не потрапили в небезпечне становище. Правила безпеки відносно добре описують умови роботи кожного конкретного фаху. Наприклад, на висоті понад два метри обов'язково слід користуватись захисною каскою та мати захисні перила; в разі вітру в 6 вузлів не можна піднімати вантаж, що в процесі підйому гойдається; на будмайданчику можуть перебувати лише особи із відповідним дозволом.

Виконання цих правил потребує дисципліни, наполегливості та відчуття постійної відповідальності. Освоєння правил перевіряється екзаменаторами, видається сертифікат, який доводить, що виконавець знає правила, відчуває відповідальність і дотримуватиметься безпеки у виконанні завдань.

Театр, цирк, естрада та інші сценічні майданчики також підлягають загальним вимогам техніки безпеки [1]. Жорстко встановлені вимоги до безпечної експлуатації технологічного і механічного обладнання, безпечної експлуатації сценічного комплексу, експлуатації електроустановок та інженерних мереж. Але специфічні особливості виконавського мистецтва часто вимагають індивідуальних рішень, які виходять за межі загаль- 
ноприйнятих правил техніки безпеки та охорони праці.

Перед оркестровою ямою не можна встановлювати перила або бар'єри, бо це обмежувало б бачення того, що відбувається на сцені. Тому край ями позначається білою лінією, яка замінює сталеві перила.

Елементи декорації важать сотні кілограмів, i без шолома, за класичними правилами техніки безпеки, під ними не можна було би перебувати і працювати. Але важко собі уявити, як би виглядали актори або танцюристи на сцені в жовтих захисних касках. А якщо потрібно поставити батальну сцену (фехтування, рукопашний бій тощо), то хоча правила безпеки вимагають запобігти травмам акторів та учасників масових сцен, але конкретне вирішення цієї проблеми покладають на постановника цих сцен.

Специфіка виконавського мистецтва вимагає особливого застосування правил безпеки життя, включає людський фактор і часто покладає відповідальність на технічних фахівців, таких як технічні оператори обладнання, менеджери сцени, освітлювачі тощо. Адже іноді за кілька секунд потрібно перемістити елементи декорації, наприклад, стіни, що важать сотні кілограмів, і при цьому артист не має змоги покинути сцену. Його безпека довірена технічному фахівцеві. Освітити акробата чи гімнаста так, щоб глядачі бачили, що вони роблять у повітрі - це питання життя i смерті. Якщо промінь прожектора на кілька сантиметрів піде вище ніж потрібно, то може осліпити артиста, який неточно виконає стрибок, руки зроблять помилковий рух, і він упаде, що може завершитися летальним кінцем.

Управління прожектором світла не автоматичне, його не можна запрограмувати, таким чином, безпека артиста знаходиться в руках техніка, який відповідає за освітлення.

Можна звернути увагу на таку особливість виконавського мистецтва: доволі часто артисти самі монтують для себе реквізит. Вони тижнями або часто навіть і місяцями розробляють спеціальні технічні пристрої, дротяні троси, натягувачі, стійки. Впродовж випробувального періоду вони самостійно змонтовують, налаштовують їх для забезпечення безпеки. Потім провадиться «живий тест», виступ.

Зрозуміло, що артисти неспроможні виконати усе самі, зробити налаштування, монтаж. Тому такі роботи виконують технічні спеціалісти, від професіоналізму яких часто залежить життя артиста. Чи добре «затягнутий» затискуючий ключ, чи добре напнутий канат, чи є вага для компенсаціï? Вертикальний канат - чи справді суворо вертикальний, до десятої частки міліметра? Чи цей канат відповідно напнутий?

Починається шоу, і вже потрібно думати про артистичну роль та художній зміст, який треба донести до глядача. Немає часу, енергії на сумніви та вагання, все відбувається у змиг ока. Треба просто довіряти колегам, які за всіма вимогами безпеки встановили все, що потрібно для успішної вистави.

Тобто специфіка безпеки життя артистів сценічного мистецтва значною мірою залежить від професіоналізму людей допоміжних професій. Це також довіра до людей, віра в їх професіоналізм, і від цього мати впевненість у тому, що не треба тремтіти за безпеку життя, не треба займатися реквізитом і завданнями монтажу, тому що монтаж і реквізит будуть зроблені на відповідному рівні. Без довіри неможливо виконати складну творчу роботу, займатися мистецтвом, досягти катарсису.

У суспільстві, при всьому захваті працею артистів, рідко згадується надзвичайна відповідальність технічного персоналу, професіоналів сценічного менеджменту, робітників допоміжних цехів. Але без них неможливий успіх вистави i потрібно вважати їх повноцінними учасниками процесу. Разом із режисером-продюсером та артистами технічний співробітник несе однакову відповідальність за успіх чи невдачу шоу, і аплодисменти звучать і для працівників, що трудяться «за завісою» [2].

Зазначимо, що режисер після отримання атестату зрілості має близько п'яти років для набуття професійних навичок, є учасником серйозного професійного процесу відбору. У Свропі актор, танцюрист, артист, в середньому, як мінімум п’ять років навчається, і суспільство забезпечує йому так багато часу та можливостей для набуття навичок та знань, необхідних для професійної творчої роботи, покращення кваліфікації.

Вочевидь, те ж саме повинно стосуватися і підготовки технічних фахівців, які забезпечуватимуть творчість митця і його безпеку, адже через малу помилку життя артиста може опинитися від великим ризиком.

Технічні фахівці іноді працюють у надзвичайно важких умовах. Завжди в центрі уваги артисти, виконавці шоу, а обличчя технічного персоналу ми не бачимо, хоча й відчуваємо їх надзвичайно важливий внесок. Вони також потребують глибоких знань, необхідних для виконання роботи, тому 
на суспільство покладається відповідальність за створення належних умов передачі таких знань.

Більшість професіоналів (декоратор, суфлер, костюмер, технік, канатник, технік сцени, менеджер манежу, інспектор манежу) набувають практичні знання і досвід у процесі виконання роботи. Високо ціниться робота «стариків», тому що тільки вони можуть передати істотний професійний досвід, але це одночасно знецінює систему освіти та зменшує відповідальність суспільства в цій галузі.

В єврорпейських країнах технічних фахівців для виконавського мистецтва готують на навчальному рівні бакалаврів та магістрів. У англомовних країнах ведеться професійна підготовка працівників театру - менежер сцени (Stage Manager Ba) та сценограф (Stagedesigner), які отримують поглиблені теоретичні та практичні знання [2]. Окрім того, така підготовка надає можливість оволодіти навичками роботи 3 новим сучасним обладнанням, яке постійно оновлюється.

Але стосовно галузі циркових мистецтв у більшості європейських країн практично не відбувається передавання знань у рамках професіональних організацій і навчальних закладів. Фахівці, які відповідають за безпеку людського життя, технічні співробітники театру або цирку повинні навчатися оволодівати потрібними навичками та на основі добре виконаної роботи, як і артисти, в разі успіху повинні винагороджуватися аплодисментами глядацького залу.

Слід сподіватися, що таке положення зміниться на краще і в суспільстві з'явиться розуміння необхідності підготовки технічних фахівців для цієї галузі на належному рівні.

\section{Джерела та література}

1. Правила охорони праці для працівників театрів і концертних залів. - Наказ від 25.12.2009 р. № 210 / Державний комітет України з промислової безпеки, охорони праці та гірничого нагляду, 2009.

2. Ленглі С. Театральний менеджмент і продюсерство. Американський досвід / С. Ленглі ; пер. $з$ англ. [за ред. І. Д. Безгіна]. - К. : ВВП «Компас», 2000. - 640 с.

\section{References}

1. Pravyla okhorony pratsi dlia pratsivnykiv teatriv $\mathrm{i}$ kontsertnykh zaliv. - Nakaz vid 25.12.2009 r. № 210 / Derzhavnyi komitet Ukrainy $\mathrm{z}$ promyslovoi bezpeky, okhorony pratsi ta hirnychoho nahliadu, 2009.

2. Lenhli, S. (2000). Teatralnyi menedzhment i prodiuserstvo. Amerykanskyi dosvid / per. z anhl. [za red. I. D. Bezghina]. Kyiv : VVP «Kompas», 640 [in Ukrainian]. 